\title{
And the winners are ...
}

\section{Here are the official 1996 ACRL election results}

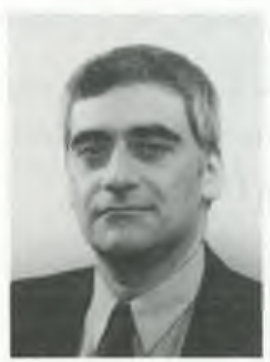

William Miller

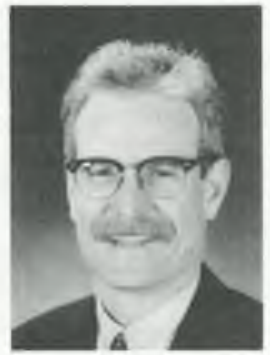

W. Lee Hisle
William Miller, director of libraries at Florida Atlantic University (FAU), is the 59th president of ACRL. When asked about his plans, Miller said, "I'm humbled by the opportunity to serve ACRL in this capacity, Among other things, I hope to help members better understand and implement the new Strategic Plan; establish the underpinnings of our new continuing education program; and work on strengthening our relationships with our state and regional chapters, looking toward the establishment of a legislative network in particular. We also need to be involved in all of ALA's initiatives, so that they fully reflect the concerns of academic and research librarians."

As president, Miller will preside over the ACRL Board of Directors and ACRL Executive Committee, chair the ACRL Conference Program Planning Committee for the 1997 Annual Conference, and plan ACRL's major program at the conference. He will also represent ACRL on the ALA Washington Conference Program Planning Committee and on the ALA Planning and Budget Assembly, and will represent ACRL and ALA in their relations with other organizations.

Miller has been at FAU since 1987. Before that he served as associate dean of libraries at Bowling Green State University, head of reference and government documents at Michigan
State University, and reference librarian at Albion College.

In ALA he has served on the Coordinating Committee on Access to Information, and on many committees and programs of ALA divisions. In ACRL he has served as chair of the Bibliographic Instruction Section (1984-85), on the Budget and Finance Committee (1992present), on the Choice Editorial Board (198082), on the Planning Committee (1988-90), and as chair of the Professional Liaison Committee (1994-present).

In the Michigan Library Association Miller has served as chair of the Academic Division/ ACRL Chapter, on the Editorial Board of $\mathrm{Michi}$ gan Librarian, and on the Executive Board. He has also been active in the Southeast Florida Library Information Network and the Center for Research Libraries.

W. Lee Hisle, associate vice-president of Learning Resource Services at Austin Community College (ACC), has been elected vice-president/ president-elect of ACRL. Hisle is excited about his election, noting that it is the first time in more than 30 years that a representative of a community college has been elected to lead ACRL. Hisle hopes to concentrate his efforts on increasing the influence of academic librarians in the national information policy debates, collaborating with higher education organizations, promoting library advocacy, and developing continuing education opportunities.

Hisle has previously served as director and dean of Learning Resource Services at ACC (1985-95); coordinator of Learning Resource Services at Rio Grande and Health Sciences Campuses, ACC (1980-85); and library director of the Lexington Technical Institute at the University of Kentucky Community College System (1976-80).

In ALA Hisle has served as a member of the Council since 1994; on the ALA Standards Committee, and as its chair in 1995-96; and on the Committee on Organization. In ACRL he has served as councilor (1994-1996); on the Board of Directors and Executive Committee; cn the Choice Editorial Board, and as its chair in 
1992-94; on the Budget and Finance Committee; on the Standards and Accreditation Committee; and as chair of the Community and Junior College Libraries Section.

Hisle has also been active in the Texas Library Association and in 1995 he received ACRL's EBSCO Community College Learning Resources Leadership Award.

The rest of the ACRL election results follow. The elected candidate is given first, with the number of votes received in parentheses.

\section{ACRL}

Vice-President/President-Elect: W. Lee Hisle (1,511); Bernard Fradkin (861).

To amend the Bylaws, Article VI, Section 2B: Yes (2,129) ADOPTED: No (195).

To amend the Bylaws, Article XI, Section I: Yes $(2,072)$ ADOPTED: No (234).

\section{Afro-American Studies Librarians \\ Section}

Vice-Chair/Chair-Elect: Itibari M. Zulu (37); Sylvia Y. Curtis (23)

Secretary: Carol Ritzen Kem (32); Alice Reviere Smith (24).

Member-at-Large (1 year): Mary G. Wrighten (29); Heather Martin (25).

Member-at-Large ( 2 years): Stanton F. Biddle (45); Mark G. R. McManus (13).

\section{Anthropology and Sociology Section}

Vice-Chair/Chair-Elect: Joyce L. Ogburn (111); write in (0).

Member-at-Large: Gary A. McMillan (71); Gregory A. Finnegan (46).

\section{Arts Section}

Vice-Chair/Chair-Elect: Stephen C. Bloom (96); Henry J. DuBois (61).

\section{Asian, African, and Middle Eastern Section}

Vice-Chair/Chair-Elect: Robert B. Marks Ridinger (75); write in (2).

Member-at-Large (two elected): Peter Malanchuk (41)*; Margaret Wang (47); Talbott Huey (41); Ann Wood (39)

\section{College Libraries Section}

Vice-Chair/Chair-Elect: Larry Oberg (321); Damon Hickey (200).

Secretary: Mickey Zemon (291); Marilyn Mitchell (186).
Member-at-Large: Tara Lynn Fulton (296); Peter Deekle (199).

\section{Community and Junior College Libraries Section}

Vice-Chair/Chair-Elect: Wanda K. Johnston (152); Mary Dolven (90).

Secretary: Steven H. Hagstrom (129); Kate Hickey (106)

\section{Education and Behavioral Sciences Section}

Vice-Chair/Chair-Elect: Nancy Weissinger (142); Dorothy M. Persson (140).

Member-at-Large: Jane McKeever (182); Allison Kaplan (99).

\section{English and American Literature \\ Section}

Adoption of proposed bylaws change: Yes (84) ADOPTED: No (0).

Vice-Chair/Chair-Elect: Betty H. Day (46); Susanna Pathak (40).

Secretary: Catherine Palmer (44); Yvonne Schofer (38).

Member-at-Large: Danielle J. Uchitelle (49); Loretta P. Koch (33).

\section{Extended Campus Libraries Services Section}

Vice-Chair/Chair-Elect: Nancy Burich (143); Marie Kascus (54).

Secretary: Bettina Meyer (154); S. David Mash (44).

Member-at-Large: Monica Craig (101); Janet Feldmann (97).

\section{Instruction Section}

Vice-Chair/Chair-Elect: Randy Burke Hensley. (488); Karen Williams (448).

Secretary: Scott Mandernack (495); Suzanne Byron (404).

Member-at-Large: Rebecca Jackson (592); Beth Sandore (315).

\section{Law and Political Science Section}

Vice-Chair/Chair-Elect: Stephen Stillwell (83); Paula J. Popma (78).

Member-at-Large: Nancy Littlejohn (120); Marifran Bustion (35).

\section{Slavic and Eastern European Section} Vice-Chair/Chair-Elect: Bradley L. Schaffner (49); write in (1).

Secretary: Richard Fitusimmons (46); write in (1). 
Member-at-Large: Julie Swann (47); write in (1)

\section{Rare Books and Manuscripłs Section}

Vice-Chair/Chair-Elect: Laura Stalker (249); Marvin J. Taylor (149).

Member-at-Large: Suzy Taraba (209); William E. Brown Jr. (180).

\section{Science and Technology Section}

Vice-Chair/Chair-Elect: Allison V. Level (236);

Ann Paietta (149).

Secretary: Terry Wittig (196); Nirmala Bangalore (98); Katherine Whitley (94).

\section{Universiły Libraries Section}

Vice-Chair/Chair-Elect: Lori A. Goetsch (711); Sharon Bonk (610)

Member-at-Large (two elected): Jordan Scepanski (648); Joan Giesecke (592); Joan G. Rapp (554); Helen H. Spalding (541).

\section{Western European Specialists Section}

Vice-Chair/Chair-Elect: Kurt DeBelder (115);

Heleni Pedersoli (57).

Secretary: Roger Brisson (95); Martha Hsu (76).

Member-at-Large: Nancy S. Boerner (121);

Sarah How (51)

\section{Women's Studies Section}

Adoption of proposed bylaws change: Yes (199) ADOPTED: No (5)

\section{It takes VIZION to research the world.}

Perfect for students and professionalsanyone serious about researching.

VIZION offers a "Windowiog" Z39.50 client that's the quickand easy way to research on-line databases. With VIZION you:

- Never need to learn different interfaces

- Search multiple dacabases simultancously

- Create search historios to re-esecuteseanch

strategies yasily

- Click on hypertixt for related searches No other software offers VIZION's ability to stoce, organize and bookmark destinations with such case and power. Plus. VIZION supperts Telnet, FTT; Web browsers, Gopher and most DOS and Windows operating systems.

Order now and research the world!

$$
\begin{gathered}
\text { J } \\
\text { Call toll free: } 1-800-242-2233
\end{gathered}
$$

Email ales@sirsi.com W Wo site: hup://www,sirsi.com

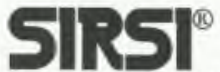

You need to reach the world. It needs to reach you. ${ }^{\text {tw }}$ Windows is a trademark of Microsof Corporation.

Vice-Chair/Chair-Elect: Jessica Grim (201); write in $(0)$.

Secretary: Barbara Heath (107); Shelley Arlen (96)

Member-at-Large: Theresa Tobin (121); Mila C. Su (86).

*Determined by lot.

\section{Letter}

To the Editor:

In her otherwise useful list of "Internet Resources for Agriculture" (June 1996), Kathleen Clark notes that environmental science is a relevant discipline, but her selection of resources focuses almost exclusively on chemical-based agribusiness, not on sustainable agriculture. Here are just a few starting points for researchers and practitioners interested in environmentally responsible agriculture:

- Agriculture Section of the Environmental Organization Webdirectory. Access: http: /www.webdirectory.com/Science/Agriculture.

- Yahoo! Sustainable Agriculture subindex. Access: http://www.yahoo.com/Science/
Agriculture/Sustainable_Agriculture/

- Yahoo! Organic Farming subindex. Access: http://www/yahoo.com/Science/Agriculture/Organic_Farming/

- Plants and Sustainable Agriculture. $A c$ cess: http://www envirolink.org/pubs/ Plants.html

- Sustainable Agriculture Educational Project. Access: http://pilot.msu.edu/user/ dunnjef1/rd491/project.htm.

- Don't Panic, Eat Organic. Access: http: /coyote.rain.org/ sals/my.html.

Yours in good health.-Jim Duyer, California State University, Cbico 